\title{
THE ECONOMIC VALUE OF THE 2010 SOCCER WORLD CUP
}

\author{
Saayman M \& Rossouw R, North-West University, Potchefstroom, South Africa.
}

Purpose: The purpose of this article is to estimate the potential economic value of the 2010 Soccer World Cup for South Africa.

Problem investigated: The Soccer World Cup (SWC) is regarded as the largest sporting event to be hosted and South Africa is investing billions of Rand in the hosting thereof. Based on this the question that comes to mind is, what is the potential economic value of such an event? Previous research attempts to determine the economic value were limited in their focus on what should be included when economic modelling of events is conducted. Most of these studies were done by consultants on behalf of various government departments and consequently, the results of these attempts are criticised for their over-inflating and overestimations by various other researchers.

Methodology: The literature review identified many aspects that need to be taken into account when modelling the economic impact of such an event together with aspects identified in the literature review. Lessons from the 2002 Korea/Japan and 2006 Germany Soccer World Cups were used as premise for our estimations. In this article, Computable General Equilibrium (CGE) modelling is used to estimate the potential economic value.

Findings: The results showed that the 2010 Soccer World Cup would in all probability have positive impacts on the economy of the country in terms of GDP growth and employment, with possible negative effects that include higher inflation and net export losses.

Value of research: The value of this research lies in the approach that was followed firstly, by introducing lessons learned from previous World Cups as well as aspects not taken into consideration previously in economic modelling and secondly, by using CGE modelling in determining the economic value.

Conclusion: The hosting of the 2010 Soccer World Cup is a major achievement not only for South Africa, but also for the rest of Africa, especially from a marketing point of view. From an economic point of view, this study shows positive results. However, compared to other studies conducted on the 2010 SWC, the findings are more conservative. The latter is supported by the results of a similar study conducted one year after the 2006 Soccer World Cup in Germany supporting the notion that various variables have to be taken into account when economic modelling for hallmark events is done.

Key words and phrases: CGE model, Soccer World Cup, Economic impact, Tourism

\section{INTRODUCTION}

Sport events are big business and have grown enormously during the last two decades. From small participatory events to the mega and hallmark events seen by millions, this industry mirrored the explosive growth of media, entertainment and tourism (Graham, Neirotti \& Goldblatt, 2001). The term sport event refers to the organisation, marketing, implementation and evaluation of any type of event related to sport. Examples are local school and community sport events, not-for-profit and corporate events (Graham et al., 2001).

Soccer is by far the largest sport in South Africa, with 2,2 million active players and $54,2 \%$ of the population as active followers and supporters. In South Africa, soccer was first played among British soldiers in Port Elizabeth in 1862. Since then, the sport has grown significantly in the number of players as well as the number of clubs. This eventually resulted in the formation of the South African Football Association in 1991. In 1996, South Africa hosted and won the African Cup of Nations (Makgabo, 2006). On 15 May 2004, it was announced that South Africa won the bid to act as host country for the 2010 FIFA Soccer World Cup (Gründlingh, 2006). The host cities which were chosen are Bloemfontein, Cape Town, Durban, Johannesburg, Nelspruit, Rustenburg, Polokwane, Pretoria and Port Elizabeth. A total of ten stadiums have been identified to host matches, of which two are located in Johannesburg (Makgabo, 2006). During the World Cup, 32 teams will play 64 matches in total. 
It is recognised that sport events are part of tourism and it is estimated that it will have a large economic impact in South Africa in the years to come (Saayman, 2001). There are numerous reasons for the increased interest in event tourism, which includes sporting events. Elected officials and their constituents realise that sport events can generate media exposure, stimulate business and infrastructure development, generate direct economic income and improve the quality of life in the community, to name but a few benefits (Graham et al., 2001). The economic impact that sport events can create has spurred many cities and countries into the event tourism arena. Many decisions are based on forecasts that are made in order to show how an event will benefit a country or destination. However, research has also shown that, in many cases, these forecasts are gross overestimations. Hence, the purpose of this article is to determine the potential economic value of the 2010 Soccer World Cup for South Africa by taking into account previous experiences. In order to achieve the purpose, the layout of the article is as follows. The introduction is followed by the literature review, thereafter the CGE approach is explained as well as the results of the modelling. Then the article concludes with implications and conclusions.

\section{LITERATURE REVIEW}

Several studies have highlighted the economic benefits derived from events in the form of tax revenues, employment, investments, infrastructure development (including housing and urban renewal) and additional sources of income (Kim, Gursoy \& Lee, 2006 and Preuss, 2000). It is estimated that South Korea has spent over 2 billion US dollars constructing its state of the art stadiums for the 2002 World Cup, in addition to costs associated with other tourism facilities such as lodging, tourism information centres, and so forth (Choo, 2002). Research estimates that World Cup tourists spend 1,8 times more than foreign leisure tourists (Lee \& Taylor, 2005). The economic benefits are derived from two sources of additional spending, namely tourist spending and organisational spending in preparing for the event.

Other benefits of an event such as this are that it offers massive marketing opportunities. As an example, research shows that two years after the Sydney Olympic Games, Australian exports have increased by $25 \%$ and its economy is still growing by $7,9 \%$ (Anon, 2006a). According to Gratton, Shibli and Coleman (2000), the Soccer World Cup has the potential to generate the largest economic impact for host nations. The opportunity to advertise products to a global audience, to leverage business opportunities in export and new investment, and for on-sell event management knowledge, enhances the tourist industry of the host country, and boosts citizen morale and pride - factors which motivate both corporate involvement and public support (Barney et al., 2002). Ritchie and Aitken (1984), as quoted by Kim et al. (2006), point out that mega-events may enhance awareness of the region or country as a domestic and/or international travel and tourism destination and also offer/create new opportunities for potential investors, which results in an increase of commercial activity within the host community.

Other critical impacts of mega-events involve improved quality of life and the international image of the host community. In fact, several researchers suggest that residents of communities that have hosted sports mega-events, such as Calgary (the 1988 Winter Olympic Games) and Georgia (the 1996 Summer Olympic Games), believe that positive social impacts of the sports mega-events (community pride and international recognition) are equally or even more important than the positive economic benefits of the event (Kim et al., 2006). In support of this, Saayman (2001) indicated that the Rugby World Cup had a positive impact on national pride in South Africa in 1995 and the same happened in the Rugby World Cup in 2007. According to Maennig (2007), the greatest benefit of the 2006 Soccer World Cup to Germany was the "feel good" effect of the German population and the improved image of the country. Residents' support for mega-events become greater if the locals perceive tourism development for mega-events as something that will improve the recreational facilities that the locals can enjoy or would increase the opportunities of recreational activities for the community (Kim, 2002).

However, research also confirms that hosting hallmark events such as the Soccer World Cup and Olympic Games have uneven economic benefits for different countries and cities. For example, the 1994 Soccer World Cup in the United States of America was rated a huge success when a record number of supporters, approximately 3,5 million, attended the event and left the organisers with large 
profits (Loots, 2006). However, Loots (2006) also indicates that even though the event was seen as an enormous success, nine of the host cities experienced income losses and only four experienced income gains. An interesting finding about the 1994 Soccer World Cup was that non-host cities experienced higher income growth, as non-soccer-related tourism was diverted from congested host cities to non-host-cities.

Gary Bailey, a former professional footballer and former ambassador on the South African bid committee for the Soccer World Cup, concluded that five industries offered the best potential for quick financial returns, namely restaurants/pubs, hotels, airlines, insurance and construction. In the case of Korea and Japan, Bailey reports that only the insurance industry made money, with all the other losing money (Anon, 2006a). This happened regardless of the fact that a survey conducted during the 2002 Soccer World Cup determined that this event generated an economic impact of US $\$ 1,35$ billion in output (sales), US\$307 million in income and US\$713 million in value added for South Korea.

Other examples of major events that were not that successful in terms of economic benefits include: the 1972 Olympic Games in Munich, with a £ 178 million loss; and the 1976 Olympic Games in Montreal, with a $£ 692$ million loss, which substantiate the perception that not all hallmark events are economically viable (Gratton et al., 2000:17). Montreal has only recently cleared their Olympics bill. Before the 1980s, therefore, it was generally accepted practice that host nations had to accept a substantial financial burden if they staged a major sporting event.

Economic impact analysis of mega-events would allow policymakers to make better informed decisions. World Cup tourists' expenditure for the 2002 World Cup was estimated to have created 31349 fulltime equivalent jobs. This is again illustrative of the substitution and crowding-out effects of mega-events, particularly if uncertainty prevails about whether the country can actually cope with the additional inflow of tourists. However, only 403466 foreign tourists (including non-World Cup tourists) arrived for the period of the 2002 World Cup. Actual tourist arrivals were $37 \%$ less than predicted and even $12,4 \%$ less than in the same month of the previous year. Negative perceptions about the behaviour of World Cup football fans, in terms of their drinking, violence and hooliganism may have been a further deterrent for non-football tourists (Loots, 2006). Another factor of displacement associated with the World Cup can be related to diversion effects; for example, Japanese tourists, who traditionally account for more than $40 \%$ of the Korean inbound market, decreased by $44,6 \%$ for the period of the World Cup (Lee \& Taylor, 2005). Reasons why the number of visitors dropped during the 2002 World Cup (Kim et al., 2006) include the following:

- A great number of potential Japanese visitors stayed home to watch the soccer matches instead of holidaying in Korea;

- The Korean government applied strict rules to Chinese influx and illegal stay after the games;

- Major travel agencies put a hold on Korean summer travel packages, in expectation of lodging shortages during the month of the World Cup; and

- The high cost of travelling to Asia.

The average attendance per match was 42 269, the lowest since the 1982 Soccer World Cup in Spain. This is, however, outbalanced by the accumulated TV audience of 40 billion viewers - the largest ever created by a single event, despite the earlier concerns of the impact of time differences.

Other problems that mega-events are also likely to create include societal problems such as traffic congestion, pollution, price increases, strain on law enforcement and increased crime (Mihalik \& Cummings; 1995 and Bohlmann, 2006). A number of studies suggest that residents do not regard the environmental damage or cost as a major concern for mega-events (see for example Mihalik \& Simonette, 1998; Ritchie \& Aitken, 1984 and Kim et al., 2006). This is an aspect that needs to be researched.

In Japan, the expectations were that the Soccer World Cup would increase the GDP by 0,3 percentage points at a time when the economy was still in the grips of a severe recession. Another 
interesting finding regarding the Korea/Japan World Cup was that consumption expenditure increased in terms of a demand for home-delivery food services, but decreased with regard to expenditure at bars. With regard to infrastructure, Korea and Japan built 10 new stadiums, two of which had to be demolished a year later because they were costing the taxpayer too much to maintain. Another major risk is the vast number of skilled people who are required. About 10000 translators will be required to direct people 18 hours a day to prevent them from getting lost, for example (Anon, 2006a).

However, it should also be kept in mind that the Soccer World Cup creates a myriad of business opportunities, such as security/emergency services and language services. The biggest of these opportunities relate to the activities of tourists between games, because tourists are prepared to travel a maximum of one to two hours to a tourist destination (Anon, 2006a). A second major opportunity is to build on the German innovation of Fan Parks. The latter can be described as huge outdoor facilities where people who do not have tickets can watch the match on huge screens.

From an economic point of view, factors such as the value of the rand and the related competitiveness of tourist packages would encourage international spectators to attend, provided that reliable transport infrastructure is available and that there are more positive indicators that crime and security can be managed (Loots, 2006). According to Grant Thornton and Kessel Feinstein (2003), the intangible benefits for the private sector for the 2010 will come from:

- substantial investment;

- increased demand for tourism facilities;

- additional revenues from similar events before and after 2010;

- public/private partnerships for the supply of equipment; and

- additional marketing opportunities.

Makgabo (2006) argues that the multiplier of the expected direct spending will have an enormous impact on the South African economy when coupled with other revenue to be spent on infrastructure, event management, tourism products and hospitality. The South African government expects to raise approximately US $\$ 1$ billion (about R 6,2 billion) in taxes.

Predictions by Grant Thornton and Kessel Feinstein (2003) estimate that the 2010 World Cup will generate R 21,3 billion for the South African economy, generating an estimated R12,7 billion in direct expenditure and creating an estimated 159000 annual new employment opportunities. It is expected that 235000 additional foreign visitors will visit the country during the World Cup year. An estimated R 2,3 billion will be spent on the upgrade of infrastructure (a figure that has already escalated to approximately $\mathrm{R} 8$ billion), and an additional $\mathrm{R} 6,2$ billion will flow back to government in the form of taxes and revenue (Loots, 2006; Gründlingh, 2006 and Magi, 2006).

However, various researchers criticise these figures because they do not make provision for aspects such as crowding out and substitution, as indicated above (Lee \& Taylor, 2005). For example, displacement (crowding-out/substitution) costs of the Los Angeles Olympics were estimated to be US\$ 163 million in out-of-region tourist expenditure that would have occurred if the Olympics had not been held. Crompton (1999) attributes this displacement to two factors: (1) continuous reporting by mass media that implied exorbitant pricing by hotels and potential congestion at the Olympic site, which negatively affected potential tourists to the site; and (2) as the Olympics site had been decided 6 years in advance, alternative vacation and business trips were planned by potential tourists. These figures too are not based on previous experiences and do not make sufficient provision for potential problems, such as expensive air travel and tour packages. Bohlmann (2006) finds that these figures are questionable and over-optimistic.

Saayman (2001) warns that a distinction must be made between sport-specific infrastructure and general infrastructure when employment and investment figures are determined. This notion is supported by Matheson and Baade (2004). Previous studies show that the Barcelona Olympic Games created 20000 jobs through Olympic-linked investments (Brunet, 2005). Madden (2002) indicates that the Sydney Olympic Games created 16500 extra jobs, while the Soccer World Cup in Germany created 50000 - fewer permanent jobs are therefore created because it is a once-off event that takes place over a short period of time. Other aspects that need to be taken in consideration are the 
demand factors for a destination. As an example, Korea attracted only 463000 tourists, which were less than the number of tourists for the same period of the previous year.

South Africa is a long-haul destination and research by Lim (2004); Lim and McAleer (2002); Crouch (1995); De Mello and Fortuna (2005); Dritsakis (2004); Smeral and Witt (1996); Song, Wong and Chon (2003) and Witt and Witt (1995) on factors which influence the demand for travel to a destination highlight the following factors:

- Income of origin country;

- Relative prices;

- Transport cost;

- Exchange rates;

- Monthly expenses; and

- Factors such as time available, destination attractiveness, etc.

In their research on demand of international travel to South Africa, Saayman and Saayman (2007) identify the following determinants of inbound tourism:

- Climate;

- Income of origin country;

- Price competitiveness; and

- Transport cost.

Hence, in order to determine or forecast the potential economic value of an event such as the Soccer World Cup 2010, a wide variety of aspects need to be taken into consideration so as not to exaggerate figures for whatever reason. A more conservative approach should be followed to prevent the creation of expectations that cannot be fulfilled. One way of addressing these problems is to base calculations on previous experiences (knowledge).

\section{SIMULATING THE ECONOMY-WIDE IMPACTS OF THE 2010 SOCCER WORLD CUP}

In order to determine the direct economic impact of the 2010 Soccer World Cup (SWC), calculations will primarily involve the expenditure on South African goods and services by soccer spectators. The impact estimations were performed by means of Computable General Equilibrium (CGE) modelling, using expenditure data. This expenditure will mainly consist of ticket sales (which in turn is the main funding source for the staging of the SWC) and travel expenditure associated with attendance of the SWC. This article will focus only on the potential once off economic effects resulting from the SWC in the year 2010.

To model the total impacts of this event, it was necessary to simulate the expenditure of overseas and local spectators in terms of the appropriate amount spent on the appropriate commodities purchased from the appropriate sources. Figures for the travel expenditure by each type of spectator for the 2006 SWC in Germany were used to model the relevant impacts. This expenditure consisted of expenditure on items such as international and domestic airfares, various other transport costs, accommodation, food and drink, shopping and entertainment.

In this section, the authors investigate the economy-wide impacts of the SWC on the South African economy by using a Computable General Equilibrium (CGE) model to simulate two scenarios. The CGE model will be briefly discussed in subsection 3.1 below and the scenarios in subsection 3.2. In subsection 3.3 the results are discussed.

\section{The CGE Approach}

Since this research is aimed at the economy-wide impacts, and in particular the impacts on household welfare, inequality and employment of the SWC event, an appropriate modelling tool is a computable general equilibrium (CGE) model. A CGE model is 'an economy-wide model that includes feedback between demand, income and production structure, and where all prices adjust until decisions made in production are consistent with decisions made in demand' (Dervis et al., 1985:132). These models 
are now well-known in policy modelling and have been used with increased frequency in South Africa since 1993 (Naudé \& Coetzee, 2004).

The model is applied (or computed) using economy-wide consistent data on a particular economy as is normally contained in a Social Accounting Matrix (SAM). In the present case, the most recent published SAM for South Africa was used (Statistics South Africa, 2004;2002). The authors also used a South African adaptation of ORANI-G to solve the model which is known as the 'DTIGEM' and was developed for the Department of Trade and Industry of South Africa by the North-West University. The DTIGEM model used in these simulations distinguishes 27 sectors, 12 household types and 4 ethnic groups (Horridge, 2000). For a more detailed exposition of the modelling approach followed in DTIGEM, see Horridge et al. (1993).

\section{Scenarios and Assumptions}

The base case scenario representing actual expenditure in all sectors is compared to a number of expenditure scenarios representing increased expenditure in certain sectors of the economy. All results presented in the tables below are in the form of percentage changes from the base case scenario.

The simulation for scenario 2 was conducted with the assumption that each household in South Africa maintained its existing average propensity to consume. Households consequently reduced their share of purchases of other goods and services to fund their SWC expenditure. In scenario 1, the simulation was conducted with the assumption that households would increase their existing and SWC related consumption.

The bulk of the direct SWC expenditure which was modelled was scheduled to take place during the specific period of the event in 2010. Consequently, the authors assumed that industries did not adjust the size of their capital stocks and also that wage rates did not adjust in response to a transient event like the SWC. This is reasonable, in that the short period involved would seem insufficient for the labour market to generate a general wage rise in response to the increased demand for labour. It is of course possible that some of the extra labour employed will be in the form of longer hours worked by existing workers. The assumption ignores the possibility that some of these hours might be at overtime rates; and even if this were the case, it is unlikely to materially affect the results (URS, 2004). A number of other noteworthy assumptions for the 2010 SWC simulation involve investment and government expenditure. It was assumed that the SWC would not induce new investment by industries, because the event is of a temporary nature.

\section{Scenario 1: The increase in household consumption on the South African economy}

In this scenario, the authors modelled the impact of a $5 \%$ increase in household consumption, based on the statistics obtained from previous SWC events held in Germany and Korea/Japan. Furthermore, the authors assumed that, due to the larger demand for goods and services, there would also be a slight increase in productivity across all sectors. It is estimated that 750000 tourists will visit South Africa, based on current arrival figures. As Kim et al. (2006) found that $57,7 \%$ of visitors to a country are there specifically for the SWC, it may be expected that about 432750 international visitors will come to South Africa in 2010 as players, officials, journalists and spectators specifically for the SWC.

Table 1: Estimated Impact on International Visitation based on Previous SWC Experiences (\%)

\begin{tabular}{lllll}
\hline Year & Germany & $\begin{array}{l}\text { Korea/ } \\
\text { Japan }\end{array}$ & $\begin{array}{l}\text { Assumed increase in } \\
\text { consumption expenditure in SA }\end{array}$ & $\begin{array}{l}\text { Year of impact } \\
\text { on SA }\end{array}$ \\
\hline \hline Event year & $10,50 \%$ & $12,60 \%$ & $5,0 \%$ & 2010 \\
\hline
\end{tabular}

Source: Anon, 2006b and Anon, 2006c

Scenario 2: The impact of increased sales in specific sectors on the SA economy

In this scenario, the authors modelled the impact of an increase in sales in specific sectors due to the increase in tourists as a result of the 2010 SWC. Based on the reported increase in the number of 
visitors during the 2006 SWC in Germany, Table 2 below illustrates the estimated increases in sales in the various sectors during the analysis period in South Africa.

\section{Table 2: Estimated increase in sales in various sectors}

\begin{tabular}{ll}
\hline Sector & Sales increase (\%) \\
\hline \hline Airline industry & $21 \%$ \\
Fuel consumption & $23 \%$ \\
Safety industry & $17 \%$ \\
Drinks industry & $16 \%$ \\
Food industry & $14 \%$ \\
Media \& film industry & $15 \%$ \\
Services industry & $10 \%$ \\
Electricity industry & $17 \%$ \\
Tourism industry & $17 \%$ \\
\hline
\end{tabular}

Source: Anon, 2006b and Anon, 2006c

\section{RESULTS}

The results are described under the headings of macro-economic results and structural impacts.

\section{Macro-Economic Results}

In the simulations, the authors implemented scenarios 1 and 2 (described in section 3.2) by shocking the variables certain exogenous variables in the DTIGEM model. This alters the expenditure patterns in the model to accurately simulate the two scenarios described above. Both scenarios (1 and 2) result in an increase in real GDP growth.

Table 3 summarizes the impacts of the two scenarios on the main macro-economic variables. Columns two and three of the table contain the results of the increase in consumption and increase in sales respectively. These simulations were performed using a short-run comparative static closure and do not imply that this event will improve long-term growth.

It should be noted that, although the two scenarios are implemented over a period of 1 year, the impact is simulated as a once-off event that plays itself out over a period of about 2-3 years. The results are then annualised and the impact can therefore be discounted back to reflect annual adjustments over the 1-year period. From Table 3, it is evident that real GDP growth increases under both scenarios on an annualised basis, though the increase is more significant under scenario $1(0.48$ per cent compared to 0.29 under scenario 2 ). 
Table 3: Impact on macro-economic variables (\% change relative to the base case)

\begin{tabular}{|c|c|c|c|c|}
\hline & Annualised \% Change & SCENARIO 1 & SCENARIO 2 & $\begin{array}{c}\text { The Effect of } \\
\text { Both Shocks } \\
\text { on the } \\
\text { Economy }\end{array}$ \\
\hline 1 & $\% \Delta$ in real GDP* (x0gdpexp) & 0.48 & 0.29 & 0.77 \\
\hline 2 & $\% \Delta$ in aggregate employment (employ_io) & 0.63 & 0.43 & 1.06 \\
\hline 3 & $\% \Delta$ in GDP price index (p0gdpexp) & 1.81 & 0.73 & 2.54 \\
\hline 4 & $\% \Delta$ in consumer prices (p3tot_h) & 1.75 & 0.51 & 2.26 \\
\hline 5 & $\% \Delta$ in average nominal wage (avewage) & 1.75 & 0.51 & 2.26 \\
\hline 6 & $\% \Delta$ in exports price index (p4tot) & 0.89 & 0.43 & 1.32 \\
\hline 7 & $\% \Delta$ in total supplies of imported goods (x0imp_c) & 1.52 & 2.35 & 3.87 \\
\hline 8 & $\% \Delta$ in export volume (x4tot) & -2.91 & -1.37 & -4.28 \\
\hline 9 & $\% \Delta$ in Import volume CIF (x0cif_c) & 1.50 & 2.31 & 3.81 \\
\hline 10 & $\% \Delta$ in competitiveness (p0realdev) & -1.78 & -0.73 & -2.51 \\
\hline 11 & $\% \Delta$ in contr government (expenditure)/GDP (delsgovsav) & -0.03 & -0.01 & -0.04 \\
\hline 12 & $\% \Delta$ in the terms of trade (p0toft) & 0.89 & 0.43 & 1.32 \\
\hline
\end{tabular}

( ${ }^{*}$ Real GDP from expenditure side)

Source: DTIGEM model results

The reason for the more favourable effect of scenario 1 (despite the deterioration in the trade balance) on GDP growth is due to higher consumer prices and an increase in domestic sales. The same is true for scenario 2, though the effects are smaller due to a smaller increase in consumer prices and because the shocks applied were focussed in specific sectors. In these results, changes in relative consumer prices and their impacts on competitiveness are important. Changes in competitiveness will affect foreign export demands and domestic demands for imports. As can be seen from Table 3, an improvement in the terms of trade of 0.89 percent (scenario 1) contributes slightly to the increase in consumer prices. On the other hand, under scenario 2, the terms of trade improvement results in a smaller increase in consumer prices. The price increase may be due to the large increase in demand resulting from the SWC event.

In scenario 1, real GDP growth ( $x$ Ogdpexp) increases by $0.48 \%$, equal to a gain of more than R5 billion for the economy and in scenario 2, real GDP growth ( $x$ ogdpexp) increases by $0.29 \%$, equal to a gain of close to R2,6 billion for the economy.

In scenario 1, higher domestic prices results in a more substantial decrease in exports $(-2.91 \%)$ than in the case of scenario $2(-1.37 \%)$. This requires an increase in export prices ( $p 4 t o t)$ and leads to an increase in imports in both scenarios, with the net result of a deterioration in the trade balance. Movements in the trade balance occur due to activity effects and relative price effects. Another reason for the higher imports in scenarios 1 and 2 are a substitution away from domestically produced goods and towards imports as consumer prices increase. The effects under scenario 2 are smaller, with a smaller decrease in consumer prices and in competitiveness.

The simulation results also indicate that employment levels will increase under both scenarios. Employment levels increase by $0.63 \%$ and $0.43 \%$ respectively due to the shocks, leading to a gain of at least 115,098 jobs in scenario 1 and 78,559 jobs in scenario 2 .

Table 3 also shows an increase in inflation under all scenarios, though the increase is more significant under scenario 1. The price increase experienced is due to increases in the average nominal wage. The price level of goods and services ( $p 3$ tot), and nominal wages (avewage) both increase by more 
than 1 percent under scenario 1 , and increases by less than 1 percent under scenario $2^{1}$. The change in the general level of prices is mainly due to changes in the terms of trade (and due the exogenous shocks applied), and the fact that real wages are held constant in this model closure, which forces nominal wages to decline with the same amount.

\section{Structural Impacts}

Tables 4 and 5 set out the structural impacts for scenario's 2 and 1 respectively.

Production volumes in South Africa under scenario 1 are higher by approximately 0.59 percent, with increased production in food processing, fuel and petroleum, electricity and water, construction, trade and most of the services sectors (see Table 5). The latter industry sectors are an important supplier of inputs for staging the 2010 SWC, such as stadium cleaning, insurance, technology support, and promotions. Other industries projected to enjoy significant positive effects are Electricity, Communication and Hotels. Table 5 shows that industries such as Trade and Transport, Printing and Publishing, Finance and Business Services, Fuel, Electricity, Communication and Hotels are among the biggest winners. Scenario 2 results in increased levels of production of 0.12 percent, mainly owing to increased demand for services and goods of many of the non-traded sectors.

The estimated employment impacts of the SWC are shown in column 9 of Tables 4 and 5 . These figures should, however, be treated with some caution, since a number of stringent assumptions are applied. For instance, no distinction is made between permanent and temporary employment, the event is a once-off short-term event, and no provision is made for working over-time. Taking this into account, the estimates provided here in terms of employment creation might still be a slight overestimation of the true employment potential of the event.

Table 4: Sector results for scenario 2 (structural effects)

\begin{tabular}{|c|c|c|c|c|c|c|c|c|c|}
\hline \multirow{2}{*}{\multicolumn{2}{|c|}{ Sector }} & \multicolumn{2}{|c|}{ Value Added } & \multicolumn{2}{|c|}{ Exports } & \multicolumn{2}{|c|}{ Imports } & \multicolumn{2}{|c|}{ Employment } \\
\hline & & $\begin{array}{c}\text { Volume } \\
\text { (x1tot) }\end{array}$ & $\begin{array}{l}\text { Price } \\
\text { (p1tot) }\end{array}$ & $\begin{array}{c}\text { Volume } \\
\text { (x4tot) }\end{array}$ & $\begin{array}{l}\text { Price } \\
\text { (p4tot) }\end{array}$ & $\begin{array}{l}\text { Volume } \\
\text { (x0imp) }\end{array}$ & $\begin{array}{c}\text { Price } \\
\text { (p0imp) }\end{array}$ & $\begin{array}{c}\text { Volume } \\
\text { (employ_op) }\end{array}$ & $\begin{array}{c}\text { Price } \\
\text { (p1lab_op) }\end{array}$ \\
\hline 1 & Agriculture & 0.00 & 1.64 & -4.86 & 1.67 & 2.77 & 0.00 & 0.01 & 1.75 \\
\hline 2 & Mining of coal & -1.22 & 0.38 & -1.58 & 0.53 & 0.03 & 0.00 & -2.36 & 1.75 \\
\hline 3 & Mining of gold & -1.36 & 0.01 & -1.37 & 0.01 & 1.77 & 0.00 & -2.36 & 1.75 \\
\hline 4 & Other mining & -1.21 & 0.39 & -1.60 & 0.54 & 0.11 & 0.00 & -2.34 & 1.75 \\
\hline 5 & Food, beverage & 0.62 & 1.78 & -5.20 & 1.80 & 2.28 & 0.00 & 1.09 & 1.75 \\
\hline 6 & Textiles, clothing & -0.30 & 1.29 & -4.01 & 1.37 & 2.89 & 0.00 & -0.41 & 1.75 \\
\hline 7 & Wood and wood & -0.53 & 1.41 & -4.37 & 1.50 & 2.14 & 0.00 & -0.76 & 1.75 \\
\hline 8 & Fuel, petroleum & 0.12 & 1.40 & -4.25 & 1.46 & 1.35 & 0.00 & 0.23 & 1.75 \\
\hline 9 & Other non-meta & -0.26 & 1.45 & -4.42 & 1.52 & 1.63 & 0.00 & -0.42 & 1.75 \\
\hline 10 & Metal products & -0.97 & 1.01 & -3.30 & 1.12 & 0.48 & 0.00 & -1.57 & 1.75 \\
\hline 11 & Electrical mach & -0.38 & 1.19 & -3.98 & 1.36 & 1.06 & 0.00 & -0.56 & 1.75 \\
\hline 12 & Electronic & -0.38 & 1.19 & -3.98 & 1.36 & 1.06 & 0.00 & -0.56 & 1.75 \\
\hline 13 & Transport equip & -0.18 & 1.00 & -3.74 & 1.28 & 3.14 & 0.00 & -0.54 & 1.75 \\
\hline 14 & Furniture and & -0.14 & 1.48 & -4.64 & 1.60 & 2.46 & 0.00 & -0.28 & 1.75 \\
\hline 15 & Electricity, gas & 0.30 & 2.58 & -7.35 & 2.58 & 1.77 & 0.00 & 1.04 & 1.75 \\
\hline
\end{tabular}

\footnotetext{
${ }^{1}$ The simulations were done using a short term comparative static closure for the model. Herein, the rate of return on capital, trade balance, technology variables and the real wage (realwage), amongst others, are taken as exogenous. On the income-side of GDP we have realwage and capital exogenous (and real cost of labour) and nominal rate of return on capital to adjust. On the expenditure-side of GDP we have $C, I, G$ exogenous, which only leaves the trade balance to adjust.
} 


\begin{tabular}{|c|c|c|c|c|c|c|c|c|c|}
\hline 16 & Water & 0.30 & 2.58 & -7.35 & 2.58 & 1.77 & 0.00 & 1.04 & 1.75 \\
\hline 17 & Construction & 0.14 & 1.47 & -4.27 & 1.47 & 0.19 & 0.00 & 0.18 & 1.75 \\
\hline 18 & Trade Services & 0.90 & 2.35 & -6.72 & 2.35 & 0.24 & 0.00 & 1.40 & 1.75 \\
\hline 19 & Accommodation & 0.24 & 1.88 & -5.45 & 1.88 & 1.07 & 0.00 & 0.36 & 1.75 \\
\hline 20 & Transport & 0.02 & 1.71 & -4.95 & 1.71 & 2.95 & 0.00 & 0.04 & 1.75 \\
\hline 21 & Post and telecom & 0.49 & 2.66 & -7.56 & 2.66 & 0.72 & 0.00 & 1.09 & 1.75 \\
\hline 22 & Finance and Ins & 0.43 & 2.36 & -6.76 & 2.36 & 0.52 & 0.00 & 0.90 & 1.75 \\
\hline 23 & Real estate & 0.43 & 2.36 & -6.76 & 2.36 & 0.52 & 0.00 & 0.90 & 1.75 \\
\hline 24 & Other business & 1.75 & 2.39 & -6.84 & 2.39 & 2.00 & 0.00 & 2.44 & 1.75 \\
\hline 25 & General govern & 1.77 & 1.75 & -5.07 & 1.75 & 1.77 & 0.00 & 1.86 & 1.75 \\
\hline 26 & Health and soc & 2.82 & 1.75 & -5.08 & 1.75 & 1.77 & 0.00 & 2.82 & 1.75 \\
\hline 27 & Other serv & -0.19 & 1.74 & -5.06 & 1.74 & 1.77 & 0.00 & -0.37 & 1.75 \\
\hline & Industry Average & 0.12 & 1.60 & -4.83 & 1.66 & 1.49 & 0.00 & 0.11 & 1.75 \\
\hline
\end{tabular}

Source: DTIGEM model results

Table 5: Sector results for scenario 1 (structural effects)

\begin{tabular}{|c|c|c|c|c|c|c|c|c|c|}
\hline \multirow{2}{*}{\multicolumn{2}{|c|}{ Sector }} & \multicolumn{2}{|c|}{ Value Added } & \multicolumn{2}{|c|}{ Exports } & \multicolumn{2}{|c|}{ Imports } & \multicolumn{2}{|c|}{ Employment } \\
\hline & & $\begin{array}{l}\text { Volume } \\
\text { (x1tot) }\end{array}$ & $\begin{array}{c}\text { Price } \\
\text { (p1tot) }\end{array}$ & $\begin{array}{l}\text { Volume } \\
\text { (x4tot) }\end{array}$ & $\begin{array}{c}\text { Price } \\
\text { (p4tot) }\end{array}$ & $\begin{array}{l}\text { Volume } \\
\text { (x0imp) }\end{array}$ & $\begin{array}{c}\begin{array}{c}\text { Price } \\
\text { (p0imp) }\end{array} \\
\end{array}$ & $\begin{array}{c}\begin{array}{c}\text { Volume } \\
\text { (employ_op) }\end{array} \\
\end{array}$ & $\begin{array}{c}\text { Price } \\
\text { (p1lab_op) }\end{array}$ \\
\hline 1 & Agriculture & -0.17 & 0.07 & -0.35 & 0.12 & -0.06 & 0.00 & -0.56 & 0.51 \\
\hline 2 & Mining of coal & -0.39 & 0.19 & -0.64 & 0.21 & 0.77 & 0.00 & -0.76 & 0.51 \\
\hline 3 & Mining of gold & -0.43 & 0.00 & -0.43 & 0.00 & -0.29 & 0.00 & -0.75 & 0.51 \\
\hline 4 & Other mining & -0.39 & 0.19 & -0.63 & 0.21 & 0.80 & 0.00 & -0.77 & 0.51 \\
\hline 5 & Food, beverage & -0.22 & 0.30 & -0.95 & 0.32 & 0.07 & 0.00 & -0.38 & 0.51 \\
\hline 6 & Textiles, clothing & -0.29 & 0.33 & -1.05 & 0.35 & 0.44 & 0.00 & -0.40 & 0.51 \\
\hline 7 & Wood and wood & 1.71 & 1.06 & -2.96 & 1.01 & 4.27 & 0.00 & 2.47 & 0.51 \\
\hline 8 & Fuel, petroleum & 0.12 & 0.52 & -1.57 & 0.53 & 0.58 & 0.00 & 0.24 & 0.51 \\
\hline 9 & Other non-meta & 3.11 & 2.39 & -5.90 & 2.05 & 5.35 & 0.00 & 5.13 & 0.51 \\
\hline 10 & Metal products & 1.10 & 1.18 & -3.29 & 1.12 & 5.09 & 0.00 & 1.79 & 0.51 \\
\hline 11 & Electrical mach & 2.62 & 1.46 & -3.91 & 1.34 & 4.44 & 0.00 & 3.94 & 0.51 \\
\hline 12 & Electronic & 2.62 & 1.46 & -3.91 & 1.34 & 4.44 & 0.00 & 3.94 & 0.51 \\
\hline 13 & Transport equip & 0.29 & 1.32 & -3.47 & 1.18 & 5.32 & 0.00 & 0.91 & 0.51 \\
\hline 14 & Furniture and & -0.14 & 0.37 & -1.22 & 0.41 & 1.48 & 0.00 & -0.29 & 0.51 \\
\hline 15 & Electricity, gas & 0.08 & 0.81 & -2.40 & 0.81 & -0.29 & 0.00 & 0.27 & 0.51 \\
\hline 16 & Water & 0.08 & 0.81 & -2.40 & 0.81 & -0.29 & 0.00 & 0.27 & 0.51 \\
\hline 17 & Construction & 6.44 & 1.79 & -5.19 & 1.79 & 4.47 & 0.00 & 7.99 & 0.51 \\
\hline 18 & Trade Services & 0.26 & 0.70 & -2.06 & 0.70 & 0.72 & 0.00 & 0.41 & 0.51 \\
\hline 19 & Accommodation & -0.10 & 0.44 & -1.30 & 0.44 & -0.04 & 0.00 & -0.15 & 0.51 \\
\hline 20 & Transport & -0.22 & 0.36 & -1.07 & 0.36 & 0.70 & 0.00 & -0.35 & 0.51 \\
\hline 21 & Post and telecom & 0.11 & 0.73 & -2.14 & 0.73 & 0.16 & 0.00 & 0.24 & 0.51 \\
\hline 22 & Finance and Ins & 0.11 & 0.71 & -2.09 & 0.71 & 0.26 & 0.00 & 0.24 & 0.51 \\
\hline 23 & Real estate & 0.11 & 0.71 & -2.09 & 0.71 & 0.26 & 0.00 & 0.24 & 0.51 \\
\hline 24 & Other business & -0.23 & 0.41 & -1.23 & 0.41 & -0.25 & 0.00 & -0.32 & 0.51 \\
\hline 25 & General govern & -0.29 & 0.59 & -1.76 & 0.59 & -0.29 & 0.00 & -0.30 & 0.51 \\
\hline 26 & Health and soc & -0.45 & 0.51 & -1.53 & 0.51 & -0.29 & 0.00 & -0.45 & 0.51 \\
\hline
\end{tabular}




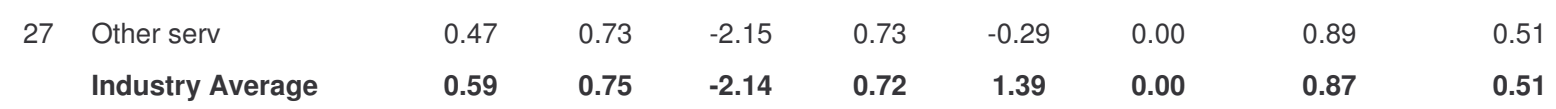

\section{Source: DTIGEM model results}

Table 6 shows the changes in employment by occupation resulting from the SWC event. From the results, it can be seen that service workers, shop and market sales workers, benefit the most under scenario 1 , whereas, craft and related traders workers, benefit more under scenario 2 . In the following section a look will be taken at the implications of this research.

Table 6: Aggregate employment (persons)

\begin{tabular}{|c|c|c|c|c|}
\hline & Occupation & SCENARIO 1 & SCENARIO 2 & $\begin{array}{c}\text { The Effect of } \\
\text { Both Shocks } \\
\text { on the } \\
\text { Economy } \\
\end{array}$ \\
\hline 1 & Legislators, senior officials and managers & 1.25 & 0.16 & 1.41 \\
\hline 2 & Professionals & 0.67 & 0.45 & 1.12 \\
\hline 3 & Technical \& associate professionals & 0.62 & 0.68 & 1.30 \\
\hline 4 & Clerks & 0.98 & 0.19 & 1.17 \\
\hline 5 & Service workers, shop \& market sales workers & 1.19 & 0.06 & 1.25 \\
\hline 6 & Skilled agric. and fishery workers & 0.51 & -0.42 & 0.09 \\
\hline 7 & Craft and related traders workers & 0.18 & 1.37 & 1.55 \\
\hline 8 & Plant and machine operators \& assemblers & -0.63 & 0.48 & -0.15 \\
\hline 9 & Elementary occupations & -0.63 & 0.48 & -0.15 \\
\hline 10 & Domestic workers & 0.20 & 0.67 & 0.87 \\
\hline 11 & Occupation unspecified & 0.62 & 0.52 & 1.14 \\
\hline
\end{tabular}

Source: DTIGEM model results

\section{IMPLICATIONS}

From this research, the following implications are evident. Firstly from a policy point of view, the impacts of hosting the SWC in 2010 are consistent with the ASGISA macro-strategy, and in a general equilibrium approach the winners and losers of the 2010 SWC become visible (in partial analyses they are invisible and only the gainers are visible). Secondly, from a methodological point of view, this research confirms that a more holistic approach to determining the economic value of events are paramount. This analysis made provision for aspects such as crowding out, which was not taken into consideration by any of the other research studies conducted for the 2010 SWC. The literature review also indicated clearly the necessity of taking into account the great number of factors which influence the number of visitors that attend the event, and thus also the magnitude of spending. These factors include transport cost, exchange rate fluctuations, tour packages and perceptions of crime. The analysis also made a distinction between general investment conducted in South Africa (such as the Gautrain project and the general upgrading of the road network) and sport-specific infrastructure investment (such as stadium upgrading and new stadiums).

Thirdly, the results obtained in this study are more conservative than those of other research already completed, due to the aspects mentioned above. Maennig (2007) reported in his article "one year later: a re-appraisal of the economics of the 2006 Soccer World Cup" that Germany has benefited in terms of employment and tourism although not significantly. In some sectors, such as retail, there may even have been negative developments. This research together with the findings of Maennig (2007) therefore cautions against too high expectations.

Fourthly, it should also be noted that the literature review highlighted the fact that the marketing and other investment benefits derived from such an event takes a number of years to show dividends. However, the fact remains that an event such as the SWC often leads to an improved image of the 
destination and that it creates positive economic impacts. One aspect that the tourism industry in South Africa, however, will have to deal with is the lack of skilled workers in the different sectors of the industry, for example accommodation, restaurants, tourist guiding, translators to name but a few. This aspect is important since it takes time to train people properly.

\section{CONCLUSIONS}

The purpose of this article was to determine the potential economic value of the 2010 SWC in South Africa, using information from previous World Cups. A Computable General Equilibrium (CGE) model was used to determine the impact, using 2 scenarios. Scenario 1 was based on an increase in private consumption expenditure of $5,0 \%$, which is consistent with statistics obtained from previous Soccer World Cup events held in Germany and Korea/Japan. Scenario 2 was based on the impact of an increase in sales, due to the increase in tourist spending in specific sectors, as a result of the 2010 SWC.

The analysis indicated that both scenarios will have positive impacts on the economy in terms of output and employment gains, especially in the services sectors. Possible negative effects include higher inflation and net export losses.

\section{REFERENCES}

Anon. 2006a. Soccer World Cup game plan. Finweek: 9 Nov.

Anon. 2006b. Presse- und Informationsamt der Bunderegierung Deutschland [Online] Available from: http://wm2006.deutschland.de/DE/Navigation/WM-Aktuell/wm-aktuell.html [Accessed: 23/02/2007].

Anon. 2006c. WM 2006 - Abschlussbericht der Bundesregierung [Online] Avialable from: http://wm2006.deutschland.de/DE/Content/SharedDocs/Publicationen/abschlussberichtbundesregierung-wm2006, property=publicationFile.pdf [Accessed: 23/02/2007].

Barney R, Wenn S \& Martyn S. 2002. Selling the five rings: The International Olympic Committee and the rise of Olympic commercialism. Salt Lake City: The University of Utah Press.

BohImann HR. 2006. Predicting the Economic Impact of the 2010 FIFA World Cup on South Africa. Pretoria: University of Pretoria.

Brunet F. 2005. The economic impact of the Barcelona Olympic Games 2003 Economic Impact Assessment [Online] Available from: http://www.olympicstudies.uab.es [Accessed: 22/02/2007].

Choo M. 2002. World cup stadiums. Korean Herald: Jul 9.

Crouch GI. 1995. A Meta-Analysis of Tourism Demand. Annals of Tourism Research, 22(1):103118.

Crompton J. 1999. Measuring the economic impact of visitors to sport tournaments and special events. Ashburn, VA: National Recreation and park Association.

De Mello MM \& Fortune N. 2005. Testing alternative dynamic systems for modelling tourism demand. Tourism Economics, 11(4):517-538.

Dritsakis N. 2004. Cointegration analysis of German and British tourism demand for Greece. Tourism Management, 25:111-119.

Gratton C, Shibli S \& Coleman R. 2006. The economic impact of major sports events: a review of ten in the UK. The Editorial Board of the Sociological Review, 41-58.

Graham S, Neirotti LD \& Goldblatt JJ. 2001. The Ultimate Guide to Sport Marketing. $2^{\text {nd }}$ ed. New York: McGraw-Hill. 
Grant Thornton \& Kessel Feinstein. 2003. Economic Impact Study of the 2010 World Cup:

Executive Summary, Jul, Johannesburg [Online] Available from: www.gthl.co.za/thl_publications.htm

Gründlingh L. 2006. Tourism in 2010. DiscourseDiskoers, 34(2).

Horridge M. 2000. ORANI-G: A generic single-country computable general equilibrium model. CoPS Working Paper OP-93, Centre of Policy Studies, Monash University

Kim HJ, Gursoy D \& Lee S. 2006. The impact $f$ the 2002 World Cup on South Korea: comparisons of pre- end post-games. Tourism Management, 27:86-96.

Kim M. 2002. World Cup boosted economy, confidence: survey. Korea Herald: Jul 9.

Lee C \& Taylor T. 2004. Critical reflections on the economic impact assessment of a mega-event: the case of 2002 FIFA World Cup. Tourism Management, 26:595-603.

Lim C. 2004. The major determinants of Korea outbound travel to Australia. Mathematics and Computers in Simulation, 64:477-485

Lim C \& Mcaleer M. 2002. A cointegration analysis of annual tourism demand by Malaysia for Australia. Mathematics and Computers in Simulation, 59:197-205.

Loots E. 2006. The 2010 Soccer World Cup: An economic and socio-economic perspective. DiscourseDiskoers, 34(2).

Madden JR. 2002. The economic consequences of the Sydney Olympics: The CREA/Arthur Andersen study. Current Issue in Tourism, 5(1):7-20.

Maennig W. 2007. One year later: A re-appraisal of the economics of the 2006 soccer World Cup. North American Association of Sports Economists. IASE/NAASE Working Paper Series, Paper No. 07-25. July 2007.

Magi LM. 2006. Possible contributions of the Soccer World Cup 2010 to the economic development of rural KwaZulu-Natal. DiscourseDiskoers, 34(2).

Makgabo T. 2006. The 2010 FIFA world cup: A development opportunity for South Africa. DiscourseDiskoers, 34(2).

Matheson VA \& Baade RA. 2004. Mega Sporting Events in Developing Nations. Working Paper 0404, College of the Holy Cross, Department of Economics.

Mihalik BL \& Cummings P. 1995. Host perceptions of the 1996 Atlanta Olympics: Support, attendance, benefits and liabilities. Travel and tourism research association $26^{\text {th }}$ annual proceedings.

Mihalik BL \& Simonette L. 1998. Resident perceptions of the 1996 Summer Olympic Games Year II. Festival Management and Event Tourism, 5(1):9-19.

Preuss H. 2000. Economics of the Olympic Games in hosting the Games 1972-2000. Walla-Walla Press in conjunction with the Centre of Olympic Studies.

Ritchie JR \& Aitken CE. 1984. Assessing the impacts of the 1988 Olympic Winter Games: the research program and initial results. Journal of Travel Research, 22(3):17-25.

Saayman M. 2001. Sport and Event tourism. Potchefstroom: Leisure C. Publications.

Saayman M \& Saayman A. 2007. The determinants of inbound tourism to South Africa. Paper presented in Advances in Tourism Economics Conference, Santo André, Portugal, 12-14 April 2007. 
Smeral E \& Witt SF. 1996. Econometric forecasts for tourism demand to 2005, Annals of Tourism Research, 23:891-907.

Song H, Wong KKF \& Chon KKS. 2003. Modelling and forecasting the demand for Hong Kong tourism. Hospitality Management, 22:435-451.

URS, 2004, "Economic Impact of the Rugby World Cup 2003 on the Australian Economy - Post Analysis", Prepared for Department of Industry, Tourism and Resources, June.

Witt SF \& Witt CA. 1995. Forecasting Tourism Demand: a review of empirical research. International Journal of Forecasting, 11:447-475. 